\title{
SUHU TUBUH: HOMEOSTASIS DAN EFEK TERHADAP KINERJA TUBUH MANUSIA
}

\author{
Yondry Kukus \\ Wenny Supit \\ Fransiska Lintong
}

\author{
Bagian Fisika Fakultas Kedokteran Universitas Sam Ratulangi Manado
}

\begin{abstract}
Body temperature is defined as one of the vital signs that indicates the health status of a person. Compared with other primates, man has a greater ability to tolerate hot temperatures due to his many sweat glands, and that his skin is covered mostly by fine hair. In our bodies, heat energy is produced by muscles (mostly), sweat glands, fats, bones, connective tissues, and nerves. Heat energy is distributed to the whole body by blood circulation, but the temperatures are not the same in all parts of the body. There is a difference (around 40C) between core and surface body temperatures. The thermoregulator system has to obtain two suitable gradients: 1) between core and surface body temperatures, and 2) between surface and ambient temperatures. The gradient between core and surface body temperatures is the most important one to maintain optimum body function. Understanding from physics the aspect of body temperature and its influence on homeostatis mechanism, gives some valuable contribution to applied clinical sciences.
\end{abstract}

Keywords: core temperature, skin temperature, energy

\begin{abstract}
Abstrak: Suhu tubuh didefinisikan sebagai salah satu tanda vital yang menggambarkan status kesehatan seseorang. Dibandingkan dengan primata lainnya, manusia mempunyai kemampuan yang lebih besar untuk mentolerer suhu tinggi oleh karena banyaknya kelenjar keringat, dan kulitnya hanya ditumbuhi oleh rambut halus. Di dalam tubuh energi panas dihasilkan oleh jaringan aktif terutama dalam otot, kemudian juga dalam alat keringat, lemak, tulang, jaringan ikat, serta saraf. Energi panas yang dihasilkan didistribusikan ke seluruh tubuh melalui sirkulasi darah, namun suhu bagian-bagian tubuh tidak merata. Terdapat perbedaan yang cukup besar (sekitar $4^{\circ} \mathrm{C}$ ) antara suhu inti dan suhu permukaan tubuh.6,7 Sistem termoregulator tubuh harus dapat mencapai dua gradien suhu yang sesuai, yaitu: 1) antara suhu inti dengan suhu per-mukaan, 2) antara suhu permukaan dengan suhu lingkungan. Dari keduanya, gradien suhu inti dengan suhu permukaan adalah yang terpenting untuk kelangsungan fungsi tubuh yang optimal. Pemahaman tentang besaran suhu dan pengaruhnya terhadap mekanisme homeostatis tubuh melalui pendekatan hukum-hukum fisika setidaknya memberi kontribusi yang berarti pada bidang ilmu klinis terapan.
\end{abstract}

Kata kunci: suhu inti, suhu kulit, energi

Telah diketahui bahwa tiap bahan terdiri dari sejumlah atom dan molekul yang selalu dalam keadaan bergerak/bergetar. Energi yang dimiliki atom atau molekul tersebut untuk bergetar disebut "energi termis". Energi termis ini dapat dijumpai dalam ba-nyak aspek kehidupan kita seharihari mulai dari urusan masak-memasak sampai urusan memanaskan besi. Makin besar energi termis yang dimiliki suatu benda maka makin panas pula benda tersebut. $^{3}$

Suhu adalah besaran yang menyatakan panas atau dinginnya suatu benda. Panas adalah energi termis yang mengalir dari suatu benda ke benda lain karena adanya perbedaan suhu. Secara alamiah panas selalu mengalir dari benda bersuhu tinggi ke benda bersuhu lebih rendah, tetapi tidak perlu dari benda berenergi termis banyak ke 
benda berenergi termis lebih sedikit. Contohnya, energi termis yang terdapat di laut jumlahnya jauh lebih banyak dibandingkan energi termis yang terdapat pada secangkir kopi panas. Bila secangkir kopi itu ke laut maka panas tidak akan mengalir dari laut ke cangkir kopi tadi, tetapi dari cangkir kopi yang bersuhu tinggi ke laut sekitarnya. Secara alami panas tidak akan pernah mengalir dari benda bersuhu rendah ke benda yang bersuhu tinggi. Dari contoh-contoh ini jelas bahwa panas dan suhu adalah dua besaran yang berbeda. ${ }^{3,14}$

\section{Definisi suhu tubuh}

Sebagian besar manusia melakukan aktivitas pada lingkungan yang "normal", yaitu pada suhu sedang pada dataran yang tidak terlalu jauh di atas permukaan laut. ${ }^{1}$ Dibandingkan dengan primata lain, manusia mempunyai kemampuan yang jauh lebih besar untuk mentoleransi suhu panas, karena banyaknya kelenjar keringat serta tubuh yang hanya berambut halus. ${ }^{4}$

Di dalam tubuh energi panas dihasilkan oleh jaringan aktif terutama dalam otot, kemudian juga dalam alat keringat, lemak, tulang, jaringan ikat, serta saraf. Energi panas yang dihasilkan didistribusikan ke seluruh tubuh melalui sirkulasi darah, namun suhu bagian-bagian tubuh tidak merata. Terdapat perbedaan yang cukup besar (sekitar $4^{\circ} \mathrm{C}$ ) antara suhu inti dan suhu permukaan tubuh.6,7 Sistem termoregulator tubuh harus dapat mencapai dua gradient suhu yang sesuai, yaitu: a) antara suhu inti dengan suhu permukaan, b) antara suhu permukaan dengan suhu lingkungan. Dari keduanya, gradient suhu inti dengan suhu permukaan adalah yang terpenting untuk kelangsungan fungsi tubuh yang optimal. Selanjutnya pertukaran panas dengan lingkungan sekitar berlangsung melalui alat pernapasan dan kulit, karna setiap usaha untuk mempertahankan suhu inti akan mempengaruhi bagian perifer tubuh terutama tangan dan kaki. $^{6,7,8}$

Dalam proses pertukaran panas tubuh mengikuti hukum fisika. Dalam hal ini tubuh manusia merupakan black body, dan permukaan tubuh merupakan penyerap panas radian yang baik sekaligus sebagai pemancar panas yang baik. Secara biologis tubuh mempunyai beberapa mekanisme untuk mempertahankan suhu tubuh:

1. Suhu tubuh inti dipertahankan dalam batas yang sempit, tubuh dapat mentoleransi variasi suhu sampai sedalam $2 \mathrm{~cm}$ dari permukaan tubuh. Suhu tubuh dapat bervariasi sekitar $1.5^{\circ} \mathrm{C}$ di atas atau di bawah suhu inti tanpa memberi efek yang berbahaya.

2. Mekanisme kontrol otomatis dari sistem saraf dan endokrin yang bekerja bila suhu inti atau suhu kulit berubah, mekanisme ini menyulitkan pengukuran kering panas.

3. Mekanisme perilaku dan perubahan postural yang dapat memodifikasi pemaparan terhadap radiasi dan konveksi panas, namun pekerja biasanya tidak bebas untuk menggunakan metode ini.

4. Penggunaan pakaian yang cocok dan menciptakan lingkungan yang protektif mulai dari api pemanasan sampai AC. ${ }^{9}$

\section{Definisi suhu inti}

Sebagian besar panas yang diproduksi di dalam tubuh merupakan hasil oksidasi, maka sumber utama panas adalah jaringan yang paling aktif, yaitu hati, kelenjar sekresi, dan otot. Ketiganya merupakan lebih dari separuh tubuh, begitulah maka suhu masing-masing jaringan dapat berbeda tergantung pada derajat metabolismenya, kecepatan darah yang mengalir ke dalamnya, dan perbedaan suhunya dengan jaringan disekitarnya. $^{2}$

Suhu yang diukur serentak di mulut, ketiak, dan pelepasan (rektum) biasanya berbeda meskipun tidak lebih dari $1^{\circ} \mathrm{C}$. Hasil pengukuran pelepasan suhu biasanya yang tertinggi, sehingga suhu ini dianggap sebagai petunjuk yang terbaik bagi suhu inti tubuh. Karena suhu rektal dapat mencapai $0,3^{\circ} \mathrm{C}$ lebih tinggi dari suhu aorta, maka panas di dalam rektum itu diduga merupakan hasil kerja bakteri. Sebaliknya, mungkin saja dijumpai suhu pelepasan yang lebih rendah dan suhu aorta bila kaki dingin. Suhu 
ketiak dapat dikata selalu lebih rendah (biasanya $0,6^{\circ} \mathrm{C}$ ) dari suhu mulut apalagi pengukurannya cukup sulit untuk mendapatkan hasil yang teliti. Suhu pelepasan maupun suhu ketiak dapat sedikit saja berubah bila darah dipanaskan ataupun didinginkan dengan cepat. Suhu paling tinggi dicapai pada sore hari sedangkan yang terendah pada dini hari, sehingga suhu ini sama sekali tidak berkaitan dengan suhu lingkungan. Melakukan aktivitas fisik berarti akan meningkatkan produksi panas, dan akan menyebabkan kenaikan suhu mulut sebesar $1-2^{\circ} \mathrm{C}$ sehingga mencapai $39^{\circ} \mathrm{C}$. Berdasarkan teori, jenis kelamin tidak mempengaruhi suhu tubuh. Faktor yang mempengaruhi suhu tubuh adalah faktor hormon, dimana pada wanita suhu tubuh dapat bergeser sesuai dengan saat-saat dalam daur haid, yaitu mulai sedikit naik sesudah ovulasi sekresi progesteron dan baru akan turun kembali sebelum haid. Pada anak-anak suhu tubuh biasanya lebih tinggi daripada orang dewasa, sedangkan pada usia lanjut ataupun bayi yang baru lahir suhunya lebih rendah, Sehingga dari hal diatas dapat diambil kesimpulan bahwa semakin bertambahnya usia maka suhu tubuh akan semakin rendah. ${ }^{15,16,17}$

\section{Definisi suhu kulit}

Di daerah yang beriklim dingin, suhu tubuh hampir selalu lebih tinggi dibanding suhu lingkungan dan selalu saja terjadi kehilangan panas lewat kulit, sehingga suhu kulit dapat mencapai $17^{\circ} \mathrm{C}$ bila suhu udara cukup dingin. Oleh karenanya terdapat perbedaan suhu yang sangat besar antara tubuh bagian dalam, lemak kulit maupun kulit itu sendiri, misalnya bagian dalam $37,2^{\circ} \mathrm{C}$, otot $36,2^{\circ} \mathrm{C}$, lemak kulit $33,6^{\circ} \mathrm{C}$, kulit $33,0^{\circ} \mathrm{C}$ dalam ruangan yang bersuhu $18,5^{\circ} \mathrm{C}$. Suhu kulit seseorang juga dapat berbeda pada satu dan lain tempat. Di dalam ruangan yang bersuhu $18^{\circ} \mathrm{C}$ jelas bahwa suhu kulit lengan atas jauh lebih tinggi dibanding suhu ujung jari. Tentu saja gambaran hasil pengukuran suhu tidak selalu demikian, sebab adanya vasodilatasi maupun aktivitas otot dapat mempengaruhinya. Suhu kulit yang sangat bervariasi dari $20^{\circ} \mathrm{C}$ sampai $40^{\circ} \mathrm{C}$ dimana dalam keadaan suhu lingkungan yang terlalu dingin, suhunya dapat turun la-gi mencapai $18^{\circ} \mathrm{C}$ dan naik sampai $45^{\circ} \mathrm{C}$ bila panas. $^{2}$

\section{PEMINDAHAN KESEIMBANGAN PANAS TUBUH}

Jaringan tubuh sangat peka terhadap pengaruh suhu jaringan yang menyimpang banyak dari suhu $37^{\circ} \mathrm{C}$. Oleh karena itulah tubuh berusaha mempertahankan suhu tubuhnya meskipun suhu lingkungan banyak berubah. Hal ini diperoleh dengan menjaga keseimbangan antara panas yang hilang dari tubuh dengan panas yang diperoleh tubuh yang berasal dari perubahan yang terjadi didalam tubuh sendiri yang diterima dari luar. Pembuangan panas terutama lewat kulit dan saluran pernapasan, yang apabila terdapat kelebihan maka panas dibawah kulit akan terbuang. Ini dapat berlangsung dengan penghantaran langsung oleh jaringan-jaringan tubuh maupun bahan cair atau fluida yang ada didalamnya, disamping yang utama yaitu diangkut oleh aliran darah. Kulit me-lepaskan panas dengan cara pemancaran (radiasi), konveksi, ataupun penghantaran (konduksi) bila keadaan memungkinkan. ${ }^{15}$

Konduksi meliputi pemindahan panas secara langsung antara dua zat yang berbeda suhunya. Panas lebih cenderung bergerak dari daerah yang bersuhu tinggi ke daerah yang bersuhu lebih rendah. Pada umumnya suhu tubuh melebihi suhu udara atau air dikelilingnya, jadi biasanya kita mengira bahwa tubuh mengalami kehilangan panas yang tetap melalui penghantar dingin. Tetapi, apabila suhu lingkungan melebihi suhu tubuh penghantar dapat menimbulkan kenaikan panas tubuh. Pemancaran pemindahan panas melalui gerakan zat yang dipanaskan (misalnya: udara, air) akan sangat mempengaruhi tingkat penghantaran pertukaran panas tubuh. Sebagai contoh bila udara dingin diedarkan dengan cepat pada permukaan tubuh, maka kehilangan panas akan terjadi dalam jumlah yang lebih tinggi daripada jika udara panas tetap menutupi kulit. ${ }^{2,15}$

Radiasi merupakan proses fisik dimana panas dipancarkan melalui gelombang elek- 
tromagnetik. Gelombang ini sering dipancarkan oleh sumber energi dalam bentuk gelombang cahaya yang nampak. Waktu membentur, benda gelombang ini dapat diserap dan diubah menjadi panas, sebagai contoh tubuh menjadi panas ketika dibentur oleh sinar matahari. Tetapi, meskipun demikian tubuh memancarkan gelombang elektromagnetik dan dapat kehilangan panas karena radiasi, jadi proses radiasi tergantung pada kondisi lingkungan tersebut. penguapan (evaporasi) merupakan perubahan bentuk fisik dari cair ke gas. Karena proses penguapan terjadi penyerapan panas oleh zat cair, maka proses tersebut cenderung mendinginkan lingkungan sekitar. Jadi penguapan air dari permukaan tubuh menyebabkan perpindahan panas dari kulit ke lingkungan.

Keseimbangan panas dan suhu tubuh yang normal terjadi bila kecepatan produksi panas metabolik tubuh diimbangi oleh kecepatan hilangnya panas tersebut ke dalam lingkungan (Tabel 1). Perolehan panas tubuh menyebabkan peningkatan suhu tubuh, sedangkan kehilangan panas berakibat menurunnya suhu tubuh. Tubuh dapat membiarkan perubahan kecil pada suhu tubuh ini, akan tetapi bila penyimpangan terjadi antara $4^{\circ} \mathrm{C}$ sampai $5^{\circ} \mathrm{C}$ dari keadaan normal $37^{\circ} \mathrm{C}$ biasanya disertai dengan kerusakan yang menetap pada sistem saraf atau bahkan menyebabkan kematian. ${ }^{15}$

Tabel 1. Pemindahan keseimbangan panas tubuh

\begin{tabular}{ll}
\hline $\begin{array}{c}\text { Perolehan panas } \\
\text { (Heat gains })\end{array}$ & \multicolumn{1}{c}{$\begin{array}{c}\text { Pelepasan panas } \\
\text { (Heat losses })\end{array}$} \\
\hline - Metobolik & - Konveksi \\
- Metabolisme basal & - Suhu lingkungan \\
- SDA (panas & - Aliran udara \\
makanan) & - Konduksi \\
- Kerja otot (sadar) & - Merendam di air \\
- Panas tak menggigil & - Radiasi \\
- Radiasi & - Vasodilatasi kulit \\
- Gelombang panjang & - Evaporasi \\
- Gelombang pendek & - Insensible \\
- Makanan dan & perspiration \\
minuman & - Keringat \\
- Ventilasi udara panas & - Meluaskan \\
- Pengurangan panas & permukaan \\
lepas & - Ruangan yang lebih \\
- Vasokonstriksi kulit & dingin \\
\hline
\end{tabular}

\section{PENGUKURAN INDEKS STRES TU- BUH PADA TUBUH}

Lingkungan yang panas dan lembab lebih mengganggu daripada lingkungan yang kering walaupun dengan suhu lebih panas. Cuaca dingin berangin lebih tidak menyenangkan dibandingkan cuaca sangat dingin berangin tenang. Pengukuran kering cuaca dapat dilakukan dengan mengukur semua variabel fisik yang mempengaruhi laju pertukaran panas, karena laju konveksi bergantung kepada suhu udara dan kecepatan angin, laju radiasi bergantung kepada suhu permukaan benda-benda serta dinding sekitar, efisiensi evaporasi bergantung kepada suhu udara, kecepatan angin dan kelembaban, dan laju keringat juga bergantung kepada intensitas kerja. Oleh karena itu dibutuhkan berbagai pengukuran seperti:

a. suhu udara yang diukur dengan termometer yang terlindung;

b. suhu radian yang diukur dengan termometer globe (bola pada pusat dari sfer tembaga hitam);

c. kelembaban yang ditandai oleh perbedaan antara suhu bola basah dan bola kering yang dinyatakan dalam kelembaban relatif atau tekanan uap;

d. kecepatan angin yang diukur dengan katatermometer (laju pendinginan bola termometer merupakan fungsi kecepatan angin pada suhu udara tertentu) atau dengan anemometer kawat panas. ${ }^{9}$

\section{INDEKS STRES PANAS}

Berbagai usaha telah dilakukan untuk memadukan berbagai pengukuran menjadi satu indeks kering panas: ${ }^{9}$

1. Suhu efektif mengkoreksi efek kelembaban serta kecepatan angin yang berbeda, dengan memperkirakan suhu udara yang masih tersaturasi yang dirasakan ekivalen dengan suhu lingkungan yang telah diukur

2. Efek radiasi panas diintegrasikan ke dalam skala suhu efektif terkoreksi. Akan tetapi perbedaan pakaian tidak terakomodasi dengan baik dalam skala terse- 
but. Laju atau kecepatan kerja yang dapat meningkatkan panas keringat dengan faktor sepuluh atau lebih, dalam hal ini tidak dapat diperhitungkan.

Untuk menilai beban panas dalam situasi industri The American Conference of Governmental Industrial Hygienists (ACGIH, 1976), merekomendasikan batas untuk aplikasi industri berdasarkan indeks suhu bola basah (Wet Bulb Globe Temperature = WBGT). Nilai batas tersebut didasarkan pada asumsi bahwa semua pekerja yang sudah teraklimatisasi dan berpakaian lengkap serta cukup memperoleh masukan cairan dan garam, akan dapat bekerja pada kondisi yang ditentukan tanpa peningkatan suhu tubuh di atas $38^{\circ} \mathrm{C}$. Namun tidak ada dasar fisiologis yang sahih. Lagi pula kinerja fisik meningkat dengan peningkatan suhu tubuh, oleh karena itu para atlet dibiasakan melakukan "pemanasan" sebelum melakukan pertandingan."

Indeks stres panas bervariasi dan ditentukan dengan menghitung jumlah evaporasi keringat yang dibutuhkan untuk mempertahankan keseimbangan suhu dalam kondisi terukur, dihitung sebagai proporsi dari laju evaporasi maksimum yang mungkin. Cara pengukuran ini mempunyai kelebihan karena dapat digunakan untuk mengukur kondisi kerja, dalam arti:

- Apakah keadaan tersebut dapat ditoleransi selama kerja yang berkesinambungan.

- Berapa lama pekerja yang bersangkutan diharapkan dapat bertahan dalam kondisi tersebut.

- Berapa lama waktu yang dibutuhkan untuk pemulihan.

Di lapangan, perkiraan tersebut tetap perlu dibandingkan dengan keadaan sebenarnya dengan mengukur secara langsung selama bekerja dalam kondisi lingkungan yang sesuai dengan kriteria tersebut di atas, yaitu: ${ }^{9}$

- Suhu inti dengan termometer klinik.

- Denyut jantung dengan mengukur denyut nadi.
- Keringat yang keluar dengan mengukur dan menghitung berat badan yang hilang selama bekerja.

Tidak banyak yang diketahui mengenai efek stres panas yang berlangsung untuk waktu yang panjang, yang perlu diperhatikan adalah: ${ }^{9}$

- Penggantian air dan garam yang keluar melalui keringat.

- Timbulnya gangguan pengaturan suhu tubuh berupa heat stres (tekanan panas) dan heat stroke (sengatan panas).

Secara klinis sengatan panas didefinisikan sebagai peningkatan suhu inti tubuh di atas $40^{\circ} \mathrm{C}$ dan disertai dengan gejala panas, kulit kering, kejang-kejang atau koma. Sengatan panas diakibatkan karena pemaparan suhu lingkungan yang tinggi dan latihan yang berat (dalam hal ini disebut exertional heat stroke). Pada gambar di bawah ini diuraikan tentang mekanisme rangkaian kejadian perkembangan tekanan panas (heat stres) menjadi sengatan panas (heat stro$k e) .^{18}$

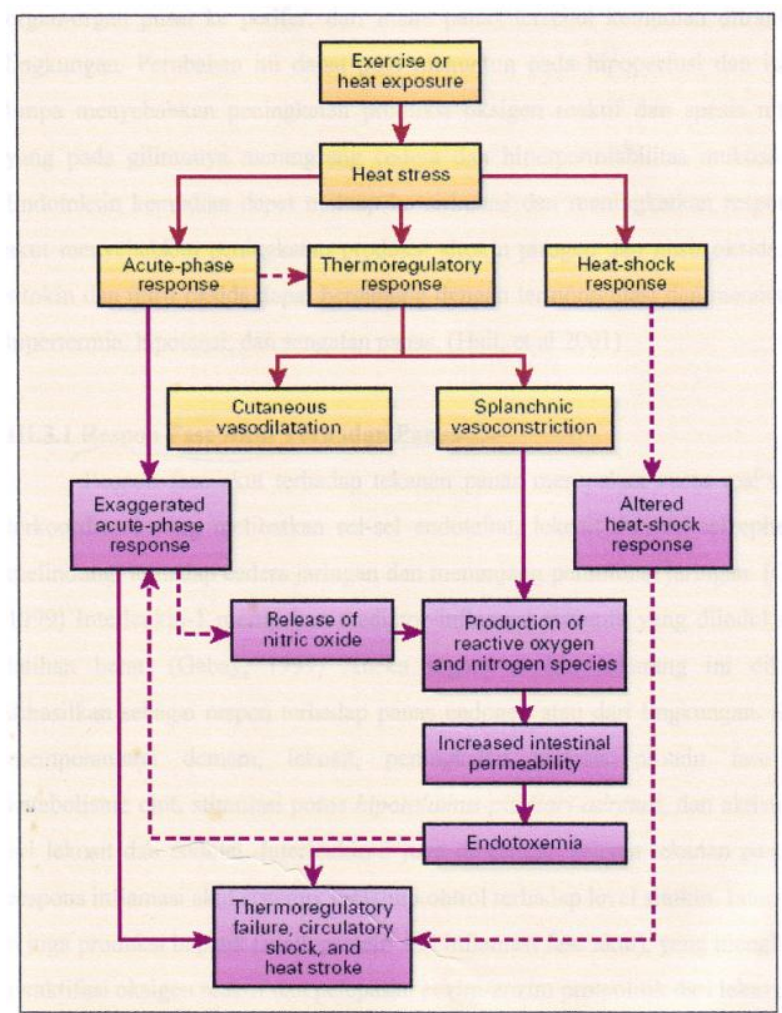

Gambar 1. Mekanisme terjadinya tekanan panas menjadi sengatan panas pada tubuh. 
Tekanan panas (heat stres) merangsang pengaturan suhu, respon fase akut dan respon syok panas. Kegagalan pengaturan suhu yang berlebihan dan perubahan ekspresi protein-protein syok secara tunggal maupun kolektif mendukung terjadinya sengatan panas. Vasodilatasi kutaneus akut dan vasokonstriksi limfatik memungkinkan pengaliran darah yang dipanaskan dari organ-organ pusat ke perifer, dimana panas tersebut kemudian ditransfer ke lingkungan. Perubahan ini dapat pula menuntun hipoperfusi dan iskemia limpa menyebabkan peningkatan produksi oksigen reaktif dan sepsis nitrogen yang pada gilirannya merangsang cedera. Endotoksin kemudian dapat meluap ke sirkulasi dan meningkatkan respon fase akut menyebabkan peningkatan produksi sitokin pirogen dan nitrit oksida. Baik sitokin dan nitrit oksida dapat bergabung dengan termoregulasi dan mencetuskan sengatan panas (heat stroke). ${ }^{19}$

Tidak terdapat perbedaan signifikan antara toleransi terhadap panas pada orang Negro dan pada orang Kaukasia. Setelah bekerja kontinu selama 1 minggu, manusia dapat beraklimatisasi terhadap kondisi lingkungan yang berada dalam rentang kemampuan toleransinya. Ia akan kembali merasa lebih nyaman dan kinerjanya meningkat. Mekanisme aklimatisasi masih belum seluruhnya jelas, namun beberapa perubahan dapat dilihat antara lain:

- Peningkatan sekresi keringat pada suhu kulit yang lebih rendah.

- Kadar garam dalam keringat lebih rendah.

- Denyut jantung menurun.

- Suhu tubuh meningkat.

Perlu pula dibedakan antara stres dan strain. Stres ialah beban yang timbul akibat kondisi iklim serta kerja fisik, sedangkan strain ialah efek yang timbul akibat stres. Ada tiga macam strain dengan cara pengukurannya: ${ }^{9}$

1. Pengalaman subjektif variabel iklim, diukur dengan kriteria nyaman atau tidak nyaman, dapat atau tidak dapat ditoleransi. Atau dapat pula dibandingkan langsung dengan parameter stres lain seperti suhu/kelembaban/kecepatan udara mana yang sesuai dengan kondisi lingkungan yang dialami.

2. Mengukur perubahan kinerja dalam melakukan uji tertentu dengan stres yang berbeda, misalnya efek kelembaban terhadap uji aritmatik atau efek suhu udara terhadap kreativitas.

3. Mengukur perubahan fungsi tubuh yang tidak dapat dikendalikan oleh kemauan seperti suhu inti, suhu kulit, denyut jantung sebagai efek langsung dari stres panas.

Pada orang sehat kondisi iklim yang dapat ditoleransi membentuk grafik lebar mendatar. Kondisi lingkungan optimal bergantung terutama kepada laju kerja fisik, karena laju pembentukan panas yang lebih tinggi membutuhkan suhu lingkungan yang lebih rendah. Pada kondisi lingkungan kerja yang normal, misalnya pekerja kantor pengeluaran panas relatif tidak tinggi. Pada kondisi tersebut suhu $19-23^{\circ} \mathrm{C}$, kelembaban $30-70 \%$, serta kecepatan angin $3-12 \mathrm{~km} /$ menit, relatif dapat diterima oleh sebagian besar orang yang sudah terbiasa dengan iklim bermusim. Pada pemaparan panas dan kerja fisik berat yang berlangsung lama, batas parameter fisik adalah: ${ }^{9}$

- Suhu inti maksimum $38^{\circ} \mathrm{C}$.

- Denyut nadi maksimum 110.

- Kehilangan air (dehidrasi) maksimum 2$3 \%$ berat badan.

- Diet (terutama air dan garam) yang adekuat untuk mengganti yang hilang melalui keringat. ${ }^{9}$

\section{INDEKS STRES DINGIN}

Masalah suhu dingin lebih mudah diatasi. Penurunan ringan pada suhu tubuh dapat ditoleransi dengan strain yang lebih ringan dibandingkan pada stres panas, akan tetapi penurunan suhu inti harus dicegah misalnya dengan pakaian yang sesuai. Telinga, hidung, serta ujung jari tangan dan kaki paling sulit dilindungi. Jari yang kedinginan dapat kehilangan rasa raba dan 
motilitas, atau terasa kebal sehingga kinerja dapat menurun dan bahkan dapat meningkatkan angka kecelakaan. Pakaian yang terlalu tebal dapat mengganggu pekerjaan, oleh karena itu bila perlu pekerja setiap selang waktu tertentu harus keluar dari tempat tersebut ke tempat yang hangat. Pemaparan terhadap kondisi dingin meningkatkan laju metabolik sehingga dapat meningkatkan kebutuhan makanan, karena makanan juga dibutuhkan untuk membentuk deposit lemak yang berfungsi sebagai isolator panas dan dibutuhkan bila pemaparan terhadap suhu dingin berlangsung lama. Untuk mengukur indeks stres dingin digunakan: ${ }^{9}$

1. Wind chill scale yang merupakan fungsi kecepatan angin pada suhu udara tertentu. Indeks ini diukur dengan mengukur waktu yang dibutuhkan oleh air untuk membeku dalam wadah logam.

2. Clo (satuan isolator pakaian) yang diukur dengan menghitung panas yang hilang dari $5.5 \mathrm{kalori} / \mathrm{m} 2 /$ jam melalui gradient $1^{\circ} \mathrm{C}$.

Rancangan pakaian sebagai isolator panas harus dapat membentuk selapis udara kering yang tidak bergerak di atas kulit atau mempertebal lapisan tersebut. Bahan yang digunakan harus berdensitas rendah, tidak menyerap keringat, dan dapat mencegah gerak udara lateral. ${ }^{1,9}$

\section{PEMBAHASAN}

\section{Mekanisme homeostatis pada suhu tubuh manusia}

\section{Suhu dingin}

Bagi individu yang beristirahat tanpa baju suhu ruang ideal adalah sekitar 28$30^{\circ} \mathrm{C}$. Dalam keadaan tersebut suhu kulit berkisar sekitar $33^{\circ} \mathrm{C}$, sedangkan suhu inti berkisar sekitar $37^{\circ} \mathrm{C}$, dan gradient antara suhu inti dan suhu kulit cukup adekuat untuk pengeluaran kelebihan panas metabolik dari jaringan yang aktif. Bila suhu ruang turun maka gradient antara suhu kulit dan suhu ruang meningkat, hal ini menyebabkan peningkatan pengeluaran panas melalui konveksi dan radiasi sehingga suhu kulit menurun. Dengan demikian darah vena yang kembali dari superfisial mempunyai suhu yang lebih rendah dan sebagian panas dari darah arteri berpindah ke darah vena. Adanya sistem counter-current antara arteri yang terletak lebih dalam dengan vena yang terletak lebih superfisial mencegah pendinginan bagian inti tubuh. Di samping itu terjadi vasokonstriksi terutama pada bagian akral, dan konduktans suhu tubuh terhadap lingkungan menurun. Dengan vasokonstriksi perifer kemampuan isolator kulit dan jaringan subkutan dapat meningkat sampai enam kali. Vasokonstriksi ini terutama terjadi pada ujung jari tangan dan kaki. ${ }^{6,7,8}$ Diperkirakan jumlah darah yang beredar pada jari-jari dapat bervariasi cukup luas dari $0,2120 \mathrm{ml} /$ menit per 100 gram jaringan, dengan mekanisme suhu jaringan perifer dapat mendekati suhu lingkungan, akan tetapi perlu diingat pula pembuluh darah di kepala tidak banyak terpengaruh oleh mekanisme ini. $^{10}$

Mekanisme untuk mempertahankan keseimbangan suhu tubuh adalah dengan meningkatkan laju metabolisme, yaitu dengan kontraksi otot (refleks menggigil). Pada keadaan menggigil terjadi aktivasi sinkron hampir semua kelompok otot bahkan otot antagonis saling berkontraksi sehingga efisiensi mekanik nol dan energi panas yang dihasilkan relatif tinggi.

Dengan mekanisme ini laju metabolik dapat meningkat 2-4 kali dibandingkan dengan laju metabolik istirahat. Sedangkan kegiatan otot dinamik biasa dapat meningkatkan laju metabolik sebesar 10 kali lipat atau lebih. Pada subjek wanita dan pria yang direndam sampai batas leher di dalam air yang berputar dan bersuhu $12^{\circ} \mathrm{C}$ terjadi refleks menggigil yang bervariasi cukup luas, V02 rata-rata selama menggigil 1,39 liter/ menit (berkisar 0,87-2,16). V02 selama menggigil ini berkorelasi signifikan dengan V02 maksimum selama kerja fisik. V02 selama menggigil berkisar sekitar $46 \%$ dari V02 maksimum.10

Walaupun sumber untuk mempertahankan suhu inti cukup efektif, usaha tersebut dapat mempengaruhi jaringan perifer. Pada keadaan yang ekstrem dapat terjadi jelas 
dingin lokal, pada pemaparan dingin yang lama pula suhu inti dapat turun. Individu tanpa pakaian dengan massa tubuh rata-rata dapat mengalami hipotermia setelah berada sekitar 20-30 menit dalam air bersuhu $5^{\circ} \mathrm{C}$ atau 1-2 jam dalam air bersuhu $15^{\circ} \mathrm{C}$. Dengan pakaian konvensional yang tebal pada individu tersebut dapat bertahan lebih lama. Penelitian pada orang yang berenang dalam air bersuhu $18^{\circ} \mathrm{C}$ memperlihatkan ambilan oksigen meningkat sekitar 0,5 liter/ menit di-bandingkan dengan berenang dengan kece-patan yang sama di dalam air yang lebih hangat.

Denyut jantung dan ambilan oksigen maksimum menurun cukup besar. Efek pemaparan terhadap air dingin moderat $\left(29^{\circ} \mathrm{C}\right)$ selama 20-30 menit akan mengganggu kinerja fisik cukup serius, bahkan berenang dapat membahayakan. Sementara itu dalam percobaannya, Vangaard (1975) mengukur suhu kulit tangan subjek yang tiba-tiba dibawa keluar dari suhu ruang $28^{\circ} \mathrm{C}$ masuk ke dalam ruang dingin bersuhu $9^{\circ} \mathrm{C}$. Suhu kulit menurun sama seperti pada subjek yang dihambat aliran darah tangannya dengan manset. Dari percobaan tersebut jelas bahwa pemaparan dingin yang tiba-tiba akan menyebabkan hambatan sirkulasi total. ${ }^{10}$

Wyon (1982) menemukan bahwa penurunan suhu ruang dari $24^{\circ} \mathrm{C}$ menjadi $18^{\circ} \mathrm{C}$ menyebabkan gangguan keterampilan manual secara signifikan. Keadaan ini mungkin disebabkan oleh perubahan kecepatan hantar saraf. Vangaard (1982) menemukan hubungan antara suhu lokal dengan kecepatan hantar saraf motor perifer pada subjek yang dipapar pada stres dingin ringan. Kecepatan hantar saraf menurun $15 \mathrm{~m} /$ detik pada setiap penurunan suhu lokal sebesar $10^{\circ} \mathrm{C}$. Pada suhu lokal $8-10^{\circ} \mathrm{C}$ ditemukan hambatan total hantaran saraf. Bergh (1980) menemukan penurunan kinerja fisik pada penurunan suhu inti, efek suhu berkisar sekitar $4-6^{\circ} \mathrm{C}$ pada kerja fisik maksimal dengan durasi kurang dari 3 menit, dan $8^{\circ} \mathrm{C}$ pada kerja fisik 3-8 menit. Kekuatan otot dinamik maksimal juga menurun dengan penurunan suhu otot. Sementara Le Blanc et al. (1978) mendapatkan bahwa pemaparan muka terhadap stimulus dingin menyebabkan pe- nurunan denyut jantung dan peningkatan vasokonstriksi perifer. Hal yang serupa juga terjadi bila muka dipapar terhadap angin dingin selama kerja fisik. Respons penurunan denyut jantung ini diduga berlangsung melalui termoregulator sentral. ${ }^{10}$

\section{Suhu panas}

Pada individu istirahat tanpa baju yang dipapar terhadap panas (suhu ruang di atas $28^{\circ} \mathrm{C}$ ), atau selama melakukan kerja otot, panas tubuh cenderung meningkat. Terjadi vasodilatasi kulit, arus balik darah berlangsung melalui vena superfisial dan konduktans jaringan meningkat. Dalam zone nyaman arus darah kulit berkisar sekitar 5\% dari volume semenit jantung. Sedangkan dalam keadaan panas hebat dapat meningkat sampai 20\% atau lebih dan dapat meningkatkan suhu kulit. Bila suhu lingkungan sekitarnya lebih rendah dari suhu kulit, maka pengeluaran panas melalui konveksi dan radiasi akan meningkat. Bila beban panas cukup besar maka kelenjar keringat akan diaktifkan dan keringat yang keluar dievaporasi sehingga suhu kulit menurun. ${ }^{10}$

Panas tubuh diperoleh dari lingkungan dan dihasilkan melalui metabolisme, kelebihan muatan panas ini harus dikeluarkan untuk menjaga suhu inti badan sekitar $37^{\circ} \mathrm{C}$, sehingga proses ini disebut termoregulasi. Respon termoregulasi refleks dan semirefleks yang diintegrasikan di dalam otak tersebut mencakup perubahan otonom, endokrin dan perilaku. Suatu peningkatan dalam suhu darah kurang dari $10^{\circ} \mathrm{C}$ mengaktivasi reseptor-reseptor panas di hipotalamus dan perifer yang memberi sinyal pada pusat termoregulator hipotalamus. Hipotalamus sendiri sering dipandang sebagai penyeimbang dan pengontrol suhu tubuh, dan juga memprakarsai terjadinya respon menggigil serta penyempitan maupun pelebaran pembuluh darah. ${ }^{20,21,22}$

Pada individu yang sudah terbiasa pada suhu panas, respons produksi keringatnya terhadap stres panas standar akan meningkat. Pemaparan terhadap panas dalam waktu yang cukup lama akan menyebabkan penurunan laju sekresi keringat walaupun 
air yang keluar diganti dengan kecepatan yang sama. Ternyata penurunan ini lebih besar pada udara lembab dibanding pada udara kering.

Ahlman dan Karvonen (1961) melaporkan bahwa kerja fisik dapat kembali menginduksi pengeluaran keringat, dan keringat akan terhenti selama stimulasi termal yang berulang dalam proses mandi sauna, supresi keringat ini berkaitan dengan kulit yang basah. Tindakan mengeringkan kulit dengan handuk atau meningkatkan gerak udara sekitar akan meningkatkan laju pengeluaran keringat. Keringat yang sudah terevaporasi akan meninggalkan solut tetap melekat pada kulit dan meningkatkan tekanan osmotik kulit. Keadaan ini tampaknya meningkatkan sekresi keringat, namun perlu diingat bahwa keringat mengandung berbagai garam, dan pengeluaran keringat yang berlebihan dapat menimbulkan kehilangan garam dalam jumlah yang cukup besar. ${ }^{10}$

\section{Efek suhu terhadap kinerja tubuh}

\section{Gerak terkoordinasi}

Kecepatan impuls saraf dan sensitivitas reseptor dipengaruhi oleh suhu jaringan. $\mathrm{Pa}-$ da suhu sekitar $5^{\circ} \mathrm{C}$ reseptor tekan dan raba tidak bereaksi terhadap stimulasi, padahal eksekusi gerak terkoordinasi bergantung kepada masukan dari reseptor tersebut. Rasa kebal pada suhu dingin merupakan akibat penurunan sensitivitas reseptor kulit. Irving (1966) melaporkan bahwa pada suhu $20^{\circ} \mathrm{C}$ sensitivitas kulit hanya seperenam kali dibandingkan sensitivitasnya pada suhu $35^{\circ} \mathrm{C}$, artinya dampak pada kulit harus 6 kali lebih besar agar dapat dirasakan pada suhu rendah. ${ }^{10}$

Kumparan otot menunjukkan peningkatan sensitivitas pada penurunan suhu otot moderat, akan tetapi pada suhu $27^{\circ} \mathrm{C}$ respons terhadap stimulus baku menurun sampai $50 \%$ dan hilang sama sekali pada suhu $15-20^{\circ} \mathrm{C}$. Fenomena ini turut mengganggu kinerja gerak halus dalam cuaca dingin dan mungkin hal ini pula yang menyebabkan peningkatan angka kecelakaan pada beberapa jenis pekerjaan manual dalam lingkungan dingin. ${ }^{10}$

\section{Kapasitas kerja mental}

Evaluasi kinerja. Mental atau intelektual selama pemaparan terhadap panas atau dingin menghadapi kendala berupa variasi subjektif dan kurangnya metoda uji objektif yang cocok. Secara umum gangguan akan terjadi pada suhu ruang melebihi $30-35^{\circ} \mathrm{C}$ bila individu sudah beraklimatisasi terhadap panas, bagi individu yang belum beraklimatisasi, batas atas untuk fungsi optimal adalah $25^{\circ} \mathrm{C}$. Gangguan yang tampak pada kemampuan kinerja mental yaitu pada kemampuan:

a. Manipulasi tepat yang membutuhkan ketangkasan dan koordinasi,

b. Mengamati isyarat optikal redup dan ireguler,

c. Tetap siaga selama uji monoton yang berlangsung lama,

d. Membuat keputusan cepat.

Selama 3 jam menggurdi hasil terbaik dicapai pada suhu $29^{\circ} \mathrm{C}$. Pada suhu ruang $33^{\circ} \mathrm{C}$ kinerja menjadi $75 \%$, suhu ruang $35^{\circ} \mathrm{C}$ menjadi $50 \%$, suhu $37^{\circ} \mathrm{C}$ menjadi $25 \%$. Motivasi yang kuat sampai batas tertentu dapat mengatasi efek suhu tersebut. ${ }^{10}$

Wyon (1979) meneliti efek stres moderat (sampai $29^{\circ} \mathrm{C}$ ) terhadap kinerja mental pada anak laki-laki dan wanita berusia 17 tahun, bahkan mereka dipapar terhadap suhu udara yang meningkat $\left(20-29^{\circ} \mathrm{C}\right)$, tipikal seperti kondisi ruang kelas yang padat. Pengertian kalimat akan menurun secara signifikan pada stres panas sedang pada sekitar jam ketiga. Pada suhu panas uji perkalian dikerjakan lebih lambat secara signifikan oleh pria dengan kemampuan minimum pada $28^{\circ} \mathrm{C}$, sedangkan memori pengenalan menunjukkan kinerja maksimum pada $26^{\circ} \mathrm{C}$ menurun secara signifikan pada suhu di atas atau di bawahnya. Astrand menemukan bahwa hasil ini mendukung hipotesis yang menyatakan penurunan kesiagaan dalam stres panas moderat dalam keadaan tanpa upaya sadar. Sementara Colquhoun, (1970) mengamati bahwa pada rentang suhu rektal yang normal kinerja uji penghitungan meningkat dan menurun bersamaan dengan suhu tubuh. ${ }^{10}$ 


\section{Faktor-faktor yang mempengaruhi suhu tubuh manusia dalam aspek klinik}

\section{Demam}

Demam adalah temperatur tubuh di atas normal $\left(>37,1^{\circ} \mathrm{C}\right)$, dapat disebabkan oleh kelainan di dalam otak sendiri atau oleh bahan-bahan toksik yang mempengaruhi pusat pengaturan suhu tubuh. Demam juga didefinisikan sebagai keadaan dimana seorang individu mengalami atau beresiko terhadap terjadinya kenaikan suhu tubuh terus menerus lebih tinggi dari $100^{\circ} \mathrm{F}$ $\left(37,8^{\circ} \mathrm{C}\right)$ per oral atau $101^{\circ} \mathrm{F}\left(38,8^{\circ} \mathrm{C}\right)$ per rektal karena faktor eksternal, yang meliputi respon terhadap pirogen (toksin, imunologi, atau agen infeksi). Penyebab demam meliputi penyakit bakteri, tumor otak, dan keadaan lingkungan yang dapat berakhir dengan serangan panas. ${ }^{2}$

Patogenesis demam terjadi karena toksin dari bakteri misalnya endotoksin bekerja pada monosit, makrofag, dan sel-sel kupffer menghasilkan berbagai macam sitokin yang bekerja sebagai pirogen endogen. Sitokin juga dihasilkan oleh sel-sel susunan saraf pusat dan apabila terjadi rangsangan oleh infeksi, maka sitokin tersebut bekerja secara langsung pada pusat-pusat pengatur suhu tubuh. Suhu tubuh yang sangat tinggi adalah berbahaya. Apabila suhu per rektal melebihi $41^{\circ} \mathrm{C}$ dalam jangka waktu yang lama maka akan terjadi kerusakan otak permanen, dan jika suhu tersebut melebihi $43^{\circ} \mathrm{C}$ maka akan timbul heat stroke dan sering mematikan. ${ }^{6}$

Klasifikasi demam menjadi tiga, yaitu: demam ringan, demam karena sengatan matahari, demam maligna, dan sindrom neuroleptik maligna. Demam yang terpenting karena sengatan matahari dan demam maligna dimana temperature dapat meningkat di atas $40,5^{\circ} \mathrm{C}$, dan keluhan permulaan dapat berupa pusing, mual, dan muntah. Tanda dan gejala demam meliputi karakteristik mayor dan karakteristik minor yang dapat di lihat pada Tabel 2. , $22^{2}$

\section{Menggigil}

Pada dasarnya temperatur darah manusia sekarang lebih rendah daripada pusat pengaturan temperatur hipotalamus yang
Tabel 2. Tanda dan gejala demam dalam aspek klinik

\begin{tabular}{|c|c|}
\hline $\begin{array}{c}\text { Karakteristik } \\
\text { Mayor }\end{array}$ & $\begin{array}{c}\text { Karakteristik } \\
\text { Minor }\end{array}$ \\
\hline $\begin{array}{l}\text { - Kulit hangat } \\
\text { - Takikardi } \\
\text { - Hepatomegali } \\
\text { - Kulit kemerahan } \\
\text { - Nyeri retroorbital } \\
\text { - Suhu tubuh lebih } \\
\text { tinggi } \\
\text { - Peningkatan } \\
\text { - pernapasan } \\
\text { - Vasodilatasi kulit } \\
\text { - Manifestasi } \\
\text { - Gerdarahan } \\
\text { - Vangguan sirkulasi } \\
\text { - Vasonstriksi kulit }\end{array}$ & $\begin{array}{l}\text { - Sakit kepala } \\
\text { - Bradikardi } \\
\text { - Malaise } \\
\text { - Sakit punggung } \\
\text { - Mual } \\
\text { - Muntah } \\
\text { - Keletihan } \\
\text { - Rasa gelisah } \\
\text { - Kelemahan } \\
\text { - Anoreksia } \\
\text { - Berkeringat }\end{array}$ \\
\hline
\end{tabular}

terjadi akibat reaksi umum yang dapat menyebabkan kenaikan temperatur tubuh. Selama periode ini orang akan menggigil dan merasa sangat kedinginan, walaupun temperatur tubuhnya mungkin telah di atas normal. Akibatnya kulit menjadi dingin karena terjadi vasokonstriksi, sehingga orang tersebut gemetaran dan proses ini berlangsung terus menerus sampai pada tingkat menggigil dan berlanjut sampai temperatur tubuh mencapai pengaturan hipotalamus $103^{\circ} \mathrm{F}$. Mengingat yang dipakai di Indonesia adalah derajat Celcius maka derajat Faren-heit akan dikonversi menjadi derajat Celcius dengan persamaan sebagai berikut: $\{5 / 9\} \mathrm{x}\left({ }^{\circ} \mathrm{F}-32\right)$ maka didapatkan $39^{\circ} \mathrm{C}^{11}$

\section{Pengaruh suhu terhadap sel dan jaringan tubuh manusia}

Penelitian garis-garis sel dan model hewan menunjukkan bahwa panas secara langsung merangsang cedera jaringan. Beratnya trauma atau cedera bergantung pada maksimum suhu kritis, suatu istilah yang mencoba untuk kadar dan lamanya pemanasan yang dapat memulai atau mengawali suatu cedera jaringan. Maksimum suhu kritis dapat melewati terjadinya suatu cedera ringan, bahkan pula mampu melewati terjadinya cedera letal atau hampir letal yang dapat di- 
tentukan pada berbagai spesies mamalia tersebut. Observasi pada kelompok-kelompok terpilih termasuk pelari-pelari maraton, sukarelawan normal, dan pasien-pasien kanker yang ditangani dengan masalah hipertermia pada seluruh tubuh yang meliputi kegagalan sirkulasi dan peningkatan kebutuhan metabolik menunjukkan bahwa maksimum suhu kritis pada manusia adalah temperatur tubuh yang mencapai $41,6^{\circ} \mathrm{C}$ sampai dengan $42^{\circ} \mathrm{C}$ selama 45 menit sampai pada delapan jam. Pada suhu ekstrim $\left(49^{\circ} \mathrm{C}\right.$ $\left.50^{\circ} \mathrm{C}\right)$ seluruh struktur seluler dihancurkan dan terjadi nekrosis seluler selama kurang dari lima menit. Pada suhu yang lebih rendah, kematian sel terutama disebabkan oleh karena terjadinya apoptosis, meskipun lintasan dari apoptosis yang diinduksi panas belum diketahui namun induksi protein sengatan panas terlindungi. ${ }^{23,24}$

\section{KESIMPULAN}

Suhu tubuh didefinisikan sebagai salah satu tanda vital yang menggambarkan status kesehatan seseorang. Energi panas dihasilkan di dalam tubuh kemudian didistribusikan ke seluruh tubuh melalui sirkulasi darah, namun suhu bagian-bagian tubuh tidak merata. Sistem termoregulator tubuh harus dapat mencapai dua gradien suhu yang sesuai, yaitu: a) antara suhu inti dengan suhu permukaan, b) antara suhu permukaan dengan suhu lingkungan. Dari keduanya, gradien suhu inti dengan suhu permukaan adalah yang terpenting untuk kelangsungan fungsi tubuh yang optimal.

\section{DAFTAR PUSTAKA}

1. Kroemer K, Kroemer H, Kroemer-Elbert K. Ergonomics. How to design for ease and efficiency. 21 edition. NJ: Prentice Hall, Upper Saddle River; 2001.

2. Guyton, Hall. Suhu tubuh, pengaturan suhu dan demam, mekanisme penyakit. Fisiologi Kedokteran, 1997; Hal. 1141-1154.

3. Gabriel JF. Pengaturan suhu tubuh. Fisika Kedokteran. Penerbit EGC, 1988; Hal. 120-130.

4. Bridger RS. Introduction to ergonomics. International editions. McGraw-Hill Inc,
1995.

5. Kalkstein LS, Valimont KM. Climate effects on human health. In Potential effects of future climate changes on forests and vegetation, agriculture, water resources, and human health. EPA Science and Advisory Committee Monograph no. 25389, 122-52. Washington, D.C.: US. Environmental Protection Agency.

6. Ganong WF. Review of medical physiology. 15th edition. California: Appleton\& Lange; 1991

7. Guyton A. Textbook of medical physiology. 8th edition. Philadelphia: W.B. Saunders Company, 1991.

8. Sherwood L. Human physiology, from cells to systems. 1st edition. St Paul: West Publishing Company, 1989.

9. Singleton WT. Introduction to ergonomics. World Health Organization. Geneva. 1972.

10. Astrand P, Rodahl K. Textbook of work physiology. New York: McGraw-Hill Company, 1986.

11. Peter S. Ilmu panas dan termodinamika, Fisika dasar, 1994; hal. 66-91.

12. Potter PA, Perry AG. Fundamentals of nursing: consepts, process \& practice. Edisi III, Mosby Year Book, 1996

13. Cameron JR. Energi suhu dan pelepasannya. Fisika Tubuh Manusia Edisi II. Jakarta: EGC, 2006; Hal. 16-33.

14. Supit W. Fisika kedokteran II, bioptik, fakultas kedokteran Unsrat, Diktat Kuliah Semester II, 2005.

15. Vander AJ, Sherman JH. Human physiology, the mechanisms of body function (6th Edition), 1970.

16. Friedman. Keperawatan keluarga. Textbook of Family Nursing. EGC: Jakarta, 1998.

17. Smith SL. Reexamining age, race, site, and thermometer type as variables affecting temperature measurement in adults: A Comparison Study.

18. Knochel JP, Reed G. Disorders of heat regulation. In: Narins R.G, ed. Maxwell \& Kleemans Clinical Disorders of Fluid And Electrolyte Metabolism (5th Edition). New York: Mc Graw-Hill, 1994; p. 1549-90.

19. Hall DM, Oberley LW. Mechanisms of circulatory and intestinal barrier dysfunction during whole body. Heart Circ 
118 Jurnal Biomedik, Volume 1, Nomor 2, Juli 2009, hlm. 107-118

Physiol. 2001; 280:509-521.

20. Robert MB, Matthew ML. Hypothalamus in: Physiology (2nd Edition). Washington DC: The C.V.Mosby Company, 1998; p. 593.

21. Mackowiak PA.. Fever: basic mechanisms and management. (2nd Edition). ed. Philadelphia: Lippincott-Raven, 1997; p. $35-40$
22. Capernito L. Buku Saku Diagnosa Keperawatan. Edisi XVII. Jakarta: EGC, 2001.

23. Sakaguchi Y, Stephens LC. Apoptosis in Tumors And Normal Tissues Induced By Whole Body Hyperthermia in Rats. Cancer Res. 1995; 55: 5459-64.

24. Polla BS, Bachelet M. Stress Proteins in Inflamation. Ann N.Y Acad Sci. 1998;851: 75-85. 